\title{
Seed Lines, Population Density, and Root Size at Harvest Affect Quality and Yield of Cut-and-peel Baby Carrots
}

\author{
Carlos A. Lazcano', Frank J. Dainello ${ }^{2}$, and Leonard M. Pike ${ }^{3}$ \\ Vegetable Improvement Center, Horticultural Sciences Department, Texas \\ A\&M University, College Station, TX 77843-2133
}

\author{
Marvin E. Miller ${ }^{4}$ and Lynn Brandenberger ${ }^{2}$ \\ Texas Agricultural Research and Extension Center, 2415 East Highway 83, \\ Weslaco, TX 78596
}

\section{Larry R. Baker 5 \\ Asgrow Seed Company, 7202 Portage Road, DeForest, WI 53532}

Additional index words. cut mass, cut waste, graded mass, graded waste, peeling line, total waste, Daucus carota

\begin{abstract}
Carrot (Daucus carota Mill. cv. Caropak) was studied under four population densities, and three numbers of seed lines per bed, and was harvested under three root size harvest parameters. Four phases (cutting, grading, peeling, and marketable yield) in the cut-and-peel baby carrot process were evaluated. Root length was most desirable when plots were harvested when $25 \%$ to $35 \%$ of the roots measured $>2 \mathrm{~cm}$ in diameter. Roots were longest $(14.7 \mathrm{~cm})$ in the treatments containing six seed lines per bed. The harvest criteria of $25 \%$ to $35 \%$ root diameter $>2 \mathrm{~cm}$ also produced the highest fresh mass $\left(48.1 \mathrm{t} \cdot \mathrm{ha}^{-1}\right)$, and the highest cut and graded mass $\left(37.7\right.$ and $32.3 \mathrm{t} \cdot \mathrm{ha}^{-1}$, respectively). A population density of 321 plants $/ \mathrm{m}^{2}$ produced the highest fresh and cut mass. Percent cut waste ( $21.6 \%$ crowns and tips) was not affected by root size at harvest, but percent graded waste was lowest $(14.2 \%)$ when plants were harvested at the greatest root size. Four seed lines per bed produced the highest graded $(18.4 \%)$, and total waste $(61.2 \%)$, but not cut waste. The lowest total waste, estimated at $59.7 \%$ and the highest projected marketable yield $\left(19.4 \mathrm{t} \cdot \mathrm{ha}^{-1}\right)$ occurred when roots were harvested using the $25 \%$ to $35 \%$ root diameter $>2-\mathrm{cm}$ parameter. Total waste and marketable yield were obtained using a fixed waste value of $40 \%$ in the peeling phase (peeling, polishing, and grading before packing). This percentage could vary depending on the equipment specifications and quality control of a given processing facility. Root size at harvest proved to be the main factor affecting projected marketable yield of cut-and-peel baby carrots at the population densities used in this study.
\end{abstract}

Despite the value and importance of carrots to the fresh-cut produce industry, and the potential for increased production, there has been little research on production technology for hybrid cultivars used for cut-and-peel baby carrots. Little is known regarding the effect of cultural practices on waste occurring along the carrot processing line. No reports are known to the authors on the effects of population density

\footnotetext{
Received for publication 16 June 1997. Accepted for publication $19 \mathrm{Dec}$. 1997. Research conducted at the Texas Agricultural Experiment Station, Weslaco. Use of trade names does not imply endorsement of the products named nor criticism of similar ones not named. We would like to acknowledge Dr. Brian K. Hamilton, Carmen Lander, and Rick Hernandez for their contribution to this project. The cost of publishing this paper was defrayed in part by the payment of page charges. Under postal regulations, this paper therefore must be hereby marked advertisement solely to indicate this fact.

'Graduate Research Assistant.

'Extension Vegetable Specialist.

${ }^{3}$ Professor and Director.

tProfessor.

${ }^{5}$ Plant Breeder.
}

and number of seed lines per bed on the length and diameter of carrot roots, and on the quality and marketable yield of cut-and-peel baby carrots, although data are available for their effects on the total fresh mass of carrots and other root crops, such as beets (Beta vulgaris L.). Goldman (1995) reported that population density affected the percentage of harvestable cylindrical red beets, but not yield or harvest mass. He reported a reduction in length and width with increasing population density. Higher population densities increase total carrot yield, but reduce the mass of individual roots (Robinson, 1969). The position of the plant in relation to its neighbor is an important factor in determining its size and shape. Increased yield and better control of carrot root size occurred when plants grown at a given density were spatially distributed as uniformly as possible (Bleasdale, 1973). The number of seed lines per bed did not affect yield of carrots at any arrangement and harvest time evaluated by Salter et al. (1980); yield was affected by population density, but was not significantly influenced by the row system under which the crop was grown.
The marketable value of the crop depends on the proper size of the carrots at harvest. Therefore, harvest time is also an important condition. Gray and Benjamin (1993) evaluated densities and row arrangements for various growing areas and cultivars of carrots. White (1994) reported that the effect of row position on the marketable mass, length, and width of carrot roots varied with season. Robinson (1969) observed that increases in stand densities were associated with a trend toward smaller plant size and a lower root mass; the lowest density ( $87 \mathrm{plants} / \mathrm{m}^{2}, 10 \mathrm{~cm}$ apart) resulted in marketable size $25 \mathrm{~d}$ before higher densities, but yield was highest at a density of 337 plants $/ \mathrm{m}^{2}, 5.1 \mathrm{~cm}$ apart. Beet root yields at 19 - and $23-\mathrm{cm}$ spacings were apparently compensated for by larger roots in the years with the better stands (Eckhoff et al., 1991).

Carrots will produce marketable roots when grown in a wide range of soil water concentrations, but high water concentrations reduce yields more than do low water concentrations (White, 1992). White and Strandberg (1979) reported that early taproot growth in organic soil can be severely reduced by periods as short as $12 \mathrm{~h}$ of exposure to a water-saturated soil environment. Continuously high soil moisture can cause root damage and forked roots (Barnes, 1936). Agung and Blair (1989) mentioned that carrot shape was more conical at high-bulk density under a low-moisture regime, and that slender carrots were produced in dense soils under high-moisture conditions.

Given the new emphasis on fresh produce, the objective of this study was to determine the quality and marketable yield of cut-and-peel baby carrots as affected by population density, seed lines per bed, and root size at harvest, as well as the effects of these factors on waste occurring in the processing line and final cut product.

\section{Materials and Methods}

The study was established on a sandy clay loam soil at the Texas Agricultural Experiment Station, Weslaco, on 28-29 Nov. 1996. Effects of three numbers of seed lines per bed (SL), four population densities (PD), and three root sizes at harvest $(\mathrm{RH})$ on the production of cut-and-peel baby carrots were evaluated in a completely randomized split-split-plot design (36 treatments). Root size at harvest (RSAH) was the main plot, SL was the split-plot, and PD the split-split-plot. Each individual treatment consisted of a row of plants $6.5 \mathrm{~m}$ long. The main plots were replicated five times.

Seed lines per bed. 'Caropak' (Asgrow Seed Co., Saticoy, Calif.) was selected for this study. This hybrid is characterized as having roots with a deep-orange interior color 22-27 $\mathrm{cm}$ long that taper slightly to a well-filled tip. Numbers of SL included in the study were four, five, and six. Carrot seeds were sown in beds $20 \mathrm{~cm}$ high, $100 \mathrm{~cm}$ center to center, and $50 \mathrm{~cm}$ wide on top of the bed. The distance from the outermost line to the edge of the bed was $7.5 \mathrm{~cm}$. in all treatments. Distances $(\mathrm{cm})$ between lines were as follows: 4 lines/bed, 
7.5; 5 lines/bed, 6.5; 6 lines/bed, 5.0. Drip irrigation was used to provide better management of water resources as well as to improve uniformity of water distribution. T-tape (TSX 508-12-450; T-systems International Inc., San Diego) was buried $15 \mathrm{~cm}$ deep in the middle of the beds. Irrigation frequency was based on subjective evaluation. A sample of soil was taken from the root zone and compacted by hand. Whenever the soil did not stay compacted, $\approx 8.4 \mathrm{~cm}$ of water was applied. Crop conditions, such as wilting, were also taken into consideration. The frequency of irrigation depended on weather conditions, but water was applied each week during the growing season. Soil samples were taken randomly across the field to determine fertilizer needs. The soil was analyzed by the Texas Agricultural Extension Service Soil Testing Laboratory, College Station, for texture, organic matter, $\mathrm{pH}$, and available macronutrients. Based on this analysis, a total of $110 \mathrm{~kg} \cdot \mathrm{ha}^{-1} \mathrm{~N}$ was applied in three applications $(45,60$, and $75 \mathrm{~d}$ after planting) through the drip irrigation system. The source of $\mathrm{N}$ was UAN (Ureaammonium nitrate, $32 \mathrm{~N}-0 \mathrm{P}-0 \mathrm{~K})$. Other nutrients were at adequate levels for crop growth. Weather information (rain, maximum-minimum temperature, relative humidity) was recorded by the meteorological station at Weslaco during the growing season. All cultural practices other than drip irrigation were as recommended by the Texas Agricultural Extension Service (Dainello, 1994).

Population density. Within each seed line treatment the population densities were 197 , 247 (commercial rate), 296, and 321 plants/ $\mathrm{m}^{2}$. Guard rows were planted between the plots. A Kincaid (Kincaid Equipment Mfg. Corp., Haven, Kans.) semiautomatic cone planter was used for sowing the seed into a 1.5$\mathrm{cm}$-wide band within each line on the bed. A germination test was performed prior to planting in order to adjust the seed sowing rate. Eighty percent of the seed produced a radicle $>1 \mathrm{~cm}$ long in $15 \mathrm{~d}$. Therefore, $30 \%$ more seed than the densest treatment were planted to assure the desired stand. The field was dripirrigated for $36 \mathrm{~h}$ immediately following planting with a pressure of $0.70 \mathrm{~kg} \cdot \mathrm{cm}^{-2}$. Seedling emergence was evident on 8 Dec. 1996. The field was thinned to stand for each treatment on 3-4 Jan. 1997. The split-plot treatment was one row $6.5 \mathrm{~m}$ long.

Root size. Root sizes evaluated were (approximate percentage with diameter $>2 \mathrm{~cm}$ ) $10 \%$ (RH I), $10 \%$ to $20 \%$ (RH II), and $25 \%$ to $35 \%$ (RH III). In this study RH I, II, and III represented early-, mid-, and late-season harvests, respectively. A section $1.8 \mathrm{~m}$ long from the split-plot was harvested for yield and quality evaluations in early, mid and late season, as determined by root size from field sampling every other day to assure desired root size for each harvest. Carrots were hand harvested, washed, and stored at $5^{\circ} \mathrm{C}$ prior to weighing. Yield at each harvest was expressed as fresh mass. The first phase of the statistical model was to analyze the three root sizes at harvest as a group and determine interactive effects of the nine dependent variables. A subsample of 20 roots was taken from each plot for diameter and length measurements.

The roots were cut, eliminating $1.3 \mathrm{~cm}$ from the top and cutting the remainder into 5$\mathrm{cm}$ pieces transversally, and eliminating the shorter pieces (tips = cut waste). The $5-\mathrm{cm}$ pieces were weighed (cut mass), hand graded to eliminate malformed pieces (grading waste), and reweighed, obtaining the graded mass.
The grading step allows quality control before the peeling process, avoids increases in waste due to low quality of the roots, and makes more efficient use of the peelers.

Values for cutting and grading wastes were analyzed for treatment effects. The parameters evaluated were: root length, root diameter, fresh mass, mass after cutting into $5-\mathrm{cm}$ pieces, percent waste after cutting, mass of the $5-\mathrm{cm}$ pieces after grading, percent waste after grading control, percent total waste, and marketable yield.

The processing procedure followed in this study (Fig. 1) was similar to the one used by a major cut-and-peel carrot producer, McManus Produce Co. of Weslaco, Tex. Percent waste in each phase of the process was calculated. The initial waste produced in this process is cut waste and includes crowns and tips of the roots. The cut waste was calculated as a percentage of fresh mass. The cut carrots were then hand graded to remove malformed pieces and those $<1.5 \mathrm{~cm}$ in diameter that did not meet quality specifications (graded waste). Graded waste was expressed as a percentage of cut mass. The 5-cm sections were not peeled because no equipment was available to handle the small sample size.

Routinely, $40 \%$ loss occurs during the peeling process, which includes shaping, polishing, and grading before packing (J. Lackey, personal communication). Therefore, this value was assumed and used as a constant for all treatments. The marketable yield was obtained at the end of the peeling and polishing estimate adjustment. Total waste produced during the processing of cut-and-peel carrots was expressed as a percentage of fresh mass.

Statistical analysis. All data were analyzed statistically using the SAS (SAS Institute, 1985)

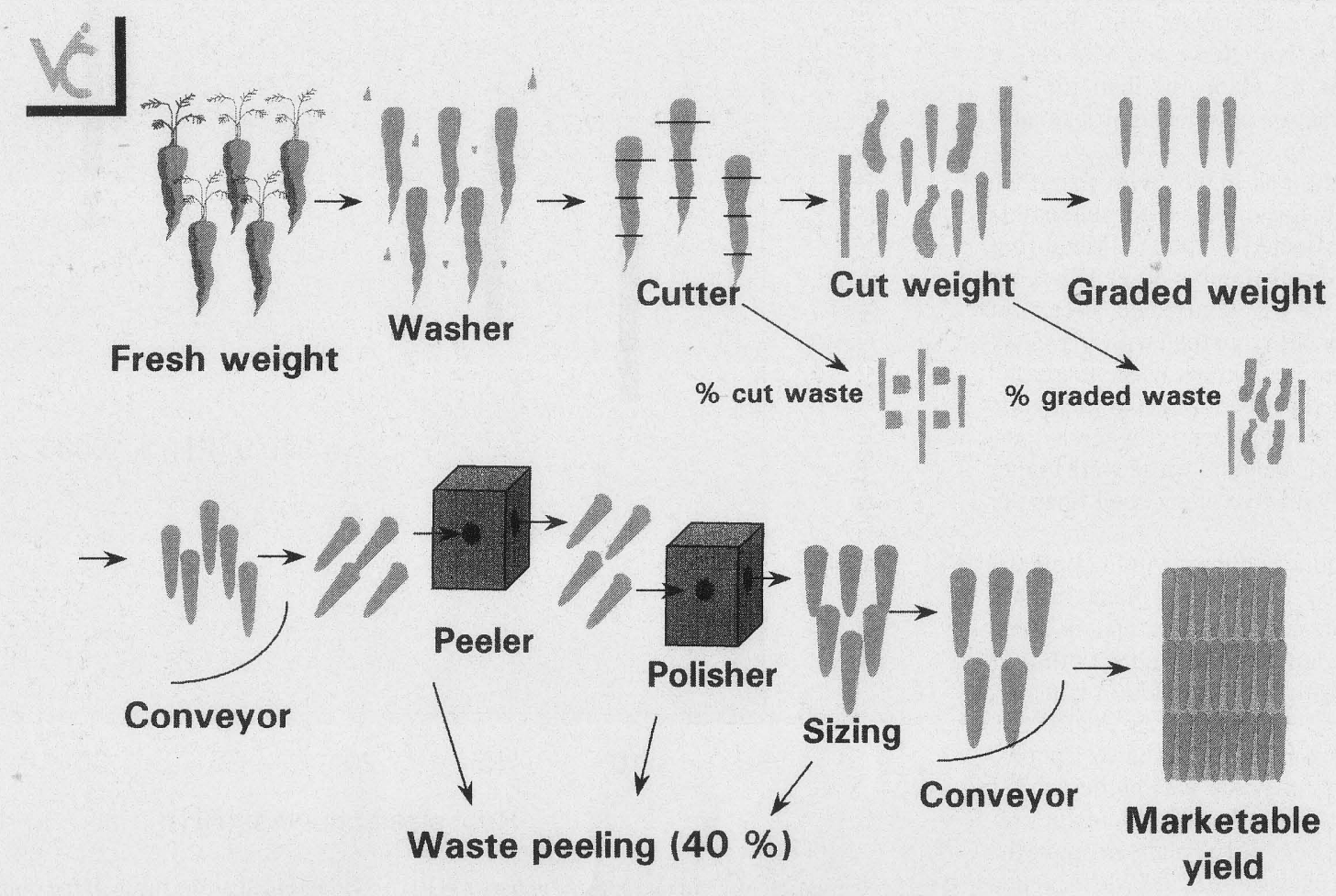

Fig. 1. Flow diagram of processing cut-and-peel baby-style carrots. 
Table 1. Main effect of seed lines per bed, population density, and root size at harvest on quality parameters influencing cut-and-peel baby-style carrots cv. Caropak at Weslaco, Tex., 1997.

\begin{tabular}{|c|c|c|c|c|c|c|c|c|c|}
\hline $\begin{array}{l}\text { Seed lines } \\
\text { per bed }\end{array}$ & $\begin{array}{c}\text { Mean } \\
\text { harvest yield } \\
\left(\mathrm{t} \cdot \mathrm{ha}^{-1}\right)\end{array}$ & $\begin{array}{c}\text { Mean root } \\
\text { length } \\
(\mathrm{cm})\end{array}$ & $\begin{array}{c}\text { Mean root } \\
\text { diameter } \\
(\mathrm{cm})\end{array}$ & $\begin{array}{c}\text { Mean } \\
\text { cut mass } \\
\left(\mathrm{t} \cdot \mathrm{ha}^{-1}\right) \\
\end{array}$ & $\begin{array}{c}\% \\
\text { Cut } \\
. \quad \text { waste }^{\mathrm{v}} \\
\end{array}$ & $\begin{array}{c}\text { Mean } \\
\text { graded mass }^{x} \\
\left(\mathrm{t} \cdot \mathrm{ha}^{-1}\right)\end{array}$ & $\begin{array}{c}\% \\
\text { Graded } \\
\text { waste }^{\text {I }}\end{array}$ & $\begin{array}{c}\% \\
\text { Total } \\
\text { waste }^{\prime} \\
\end{array}$ & $\begin{array}{c}\text { Mean } \\
\text { mkt. yield } \\
\left(\mathrm{t} \cdot \mathrm{ha}^{-1}\right) \\
\end{array}$ \\
\hline 4 & $41.6 \mathrm{a}^{4}$ & $13.9 \mathrm{c}$ & $1.5 \mathrm{a}$ & $32.8 \mathrm{a}$ & $21.0 \mathrm{~b}$ & $26.8 \mathrm{a}$ & $18.4 \mathrm{a}$ & $61.2 \mathrm{a}$ & $16.1 \mathrm{a}$ \\
\hline 5 & $39.5 \mathrm{~b}$ & $14.2 \mathrm{~b}$ & $1.5 \mathrm{a}$ & $30.9 \mathrm{~b}$ & $21.7 \mathrm{~b}$ & $25.9 \mathrm{a}$ & $16.5 \mathrm{a}$ & $60.5 \mathrm{~b}$ & $15.5 \mathrm{a}$ \\
\hline 6 & $40.4 \mathrm{~b}$ & $14.7 \mathrm{a}$ & $1.5 \mathrm{a}$ & $31.3 \mathrm{~b}$ & $22.3 \mathrm{a}$ & $26.5 \mathrm{a}$ & $15.7 \mathrm{a}$ & $60.5 b$ & $15.9 \mathrm{a}$ \\
\hline \multicolumn{10}{|c|}{ Plant density (plants/m²) } \\
\hline 197 & $39.0 \mathrm{c}$ & $14.5 \mathrm{a}$ & $1.5 \mathrm{a}$ & $31.1 \mathrm{~b}$ & $20.2 \mathrm{c}$ & $26.2 b$ & $16.2 \mathrm{a}$ & $59.6 \mathrm{c}$ & $15.7 \mathrm{a}$ \\
\hline 247 & $40.1 \mathrm{~b}$ & $14.5 \mathrm{a}$ & $1.5 \mathrm{a}$ & $31.5 \mathrm{~b}$ & $21.3 \mathrm{~b}$ & $26.4 \mathrm{~b}$ & $16.3 \mathrm{a}$ & $60.3 \mathrm{~b}$ & $19.9 \mathrm{a}$ \\
\hline 296 & $40.0 \mathrm{~b}$ & $14.2 \mathrm{a}$ & $1.5 \mathrm{a}$ & $31.2 \mathrm{~b}$ & $22.0 \mathrm{~b}$ & $25.9 \mathrm{~b}$ & $17.0 \mathrm{a}$ & $61.1 \mathrm{~b}$ & $15.5 \mathrm{a}$ \\
\hline 321 & $42.9 \mathrm{a}$ & $13.8 \mathrm{~b}$ & $1.5 \mathrm{a}$ & $32.9 \mathrm{a}$ & $23.3 \mathrm{a}$ & $27.1 \mathrm{a}$ & $17.9 \mathrm{a}$ & $62.0 \mathrm{a}$ & $16.3 \mathrm{a}$ \\
\hline \multicolumn{10}{|c|}{$\begin{array}{l}\text { Root size at harvest } \\
(\% \text { roots with diam }>2 \mathrm{~cm})\end{array}$} \\
\hline 10 & $33.9 \mathrm{c}$ & $13.2 \mathrm{c}$ & $1.3 \mathrm{c}$ & $26.5 \mathrm{c}$ & $21.7 \mathrm{a}$ & $21.4 \mathrm{c}$ & $19.4 \mathrm{a}$ & $62.1 \mathrm{a}$ & $12.8 \mathrm{c}$ \\
\hline $10-20$ & $39.6 \mathrm{~b}$ & $14.6 \mathrm{~b}$ & $1.5 \mathrm{~b}$ & $30.9 \mathrm{~b}$ & $21.8 \mathrm{a}$ & $25.6 \mathrm{~b}$ & $17.0 \mathrm{~b}$ & $61.1 \mathrm{~b}$ & $15.4 b$ \\
\hline $25-35$ & $48.1 \mathrm{a}$ & $15.0 \mathrm{a}$ & $1.9 \mathrm{a}$ & $37.7 \mathrm{a}$ & $21.6 \mathrm{a}$ & $32.3 \mathrm{a}$ & $14.2 \mathrm{c}$ & $59.7 \mathrm{c}$ & $19.4 \mathrm{a}$ \\
\hline
\end{tabular}

Values are averages of 15 to 60 samples of 20 roots each, depending upon factor.

'Mass of the 5-cm carrot pieces after cutting phase.

${ }^{x}$ Mass after grading for quality.

"Projected graded mass $-40 \%$ waste peeling phase $=$ marketable yield.

'Percent mass of crowns and tips after cutting phase.

"Percent cull mass of 5-cm carrot pieces.

Projected percentage of total waste during the processing of baby-style carrots.

Mean separation within columns and factors by LSD at $P>0.05$.

general linear model. The significance level used for the analysis of variance tables was at $P>0.05$ for the overall experiment. Mean separations were analyzed by the least significant difference (LSD) test at $P>0.05$. Linear regression was used to determine the best-fit relationship between root size at harvest and marketable yield.

\section{Results and Discussion}

The first carrots to reach marketable size (RH I, 6 LS, 197 plants $/ \mathrm{m}^{2}$ ) were harvested $113 \mathrm{~d}$ after planting, $13 \mathrm{~d}$ before any treatment in RH I. These results agree with those of Robinson (1969), who harvested 25 d earlier for densities of 87 plants $/ \mathrm{m}^{2}$ than for 337 plants $/ \mathrm{m}^{2}$. Interaction was nonsignificant at $P$ $>0.05$.

Harvest yield was higher with four than five or six seed lines, but mean marketable yield was not affected (Table 1). Mean root length increased with number of seed lines per bed, but diameter was unaffected. Mean cut mass was higher with four than with five or six lines of seed, but percent cut waste increased with lines of seed per bed. Mean graded mass was not affected significantly, whereas percent graded waste and total waste were higher with four than with five or six seed lines per bed.

Harvest yield was higher with 321 plants/ $\mathrm{m}^{2}$ than with 197,247 , or 296 plants $/ \mathrm{m}^{2}$, but mean marketable yield was not affected (Table 1). Mean root length was higher with 197 plants $/ \mathrm{m}^{2}$ than with 247,296 , or 321 plants $/ \mathrm{m}^{2}$, respectively, but diameter was unaffected. Mean cut mass was higher using 321 plants/ $\mathrm{m}^{2}$, but percent cut waste was higher at 321 plants $/ \mathrm{m}^{2}$ than with 247 or 296 plants $/ \mathrm{m}^{2}$, respectively. A density of $197 \mathrm{plants} / \mathrm{m}^{2}$ gave the lowest percent cut waste $(20.2 \%)$. Mean graded mass was higher with $321 \mathrm{plants} / \mathrm{m}^{2}$ than with 197,247 , or 296 plants $/ \mathrm{m}^{2}$, whereas percent graded waste was unaffected. Percentage total waste was lower with 197 than with 247 or 296 plants $/ \mathrm{m}^{2}$, whereas the highest total waste occurred with 321 plants $/ \mathrm{m}^{2}$.

Harvest yield increased as root size at harvest increased from $10 \%$ root diameter $>2$ $\mathrm{cm}$ to $25 \%$ to $35 \%$ (Table 1). Mean root length and root diameter both increased with larger root size at harvest. Mean cut mass was lower when harvested at $10 \%$ root diameter $>2 \mathrm{~cm}$, and higher when harvested at $25 \%$ to $35 \%$ root diameter $>2 \mathrm{~cm}$, but percent cut waste was unaffected. Mean graded mass was lower and percent graded waste and total waste were higher when harvest occurred at $10 \%$ root diameter $>2 \mathrm{~cm}$ rather than at $10 \%$ to $20 \%$, or $25 \%$ to $35 \%$. Mean marketable yield was higher when harvested at $25 \%$ to $35 \%$ root

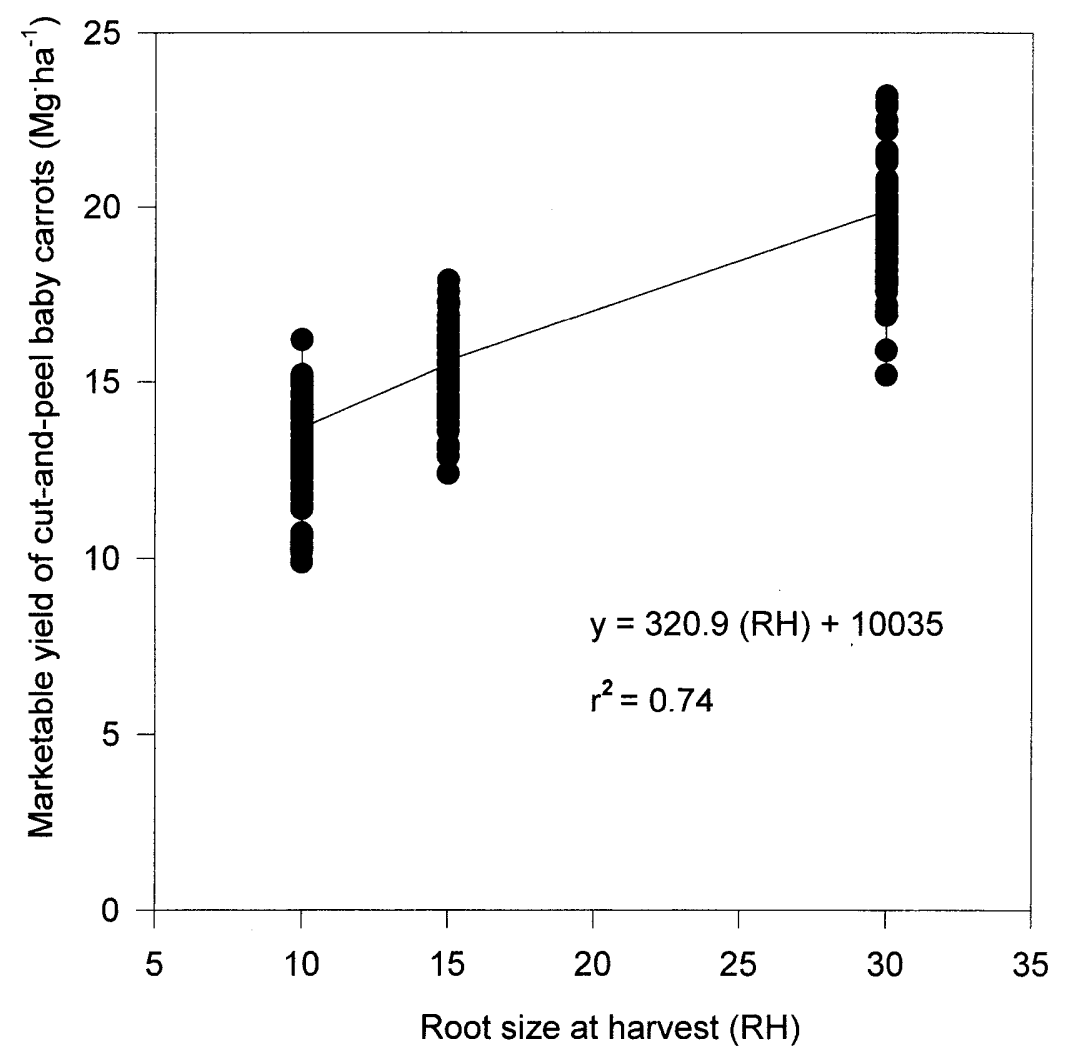

Fig. 2. Regression of yield on root size at harvest (RH); RH presented as the mean of the ranges used for each harvest with root diameter $>2 \mathrm{~cm}$. Data collected across population densities and numbers of seed lines per bed. 
diameter $>2 \mathrm{~cm}$ than when harvested at $10 \%$ to $20 \%$, or $10 \%$.

In general, marketable yield was more severely affected by root size at harvest than by any other of the main factors evaluated. The best-fit regression equation, as evaluated by coefficient of determination $\left(r^{2}\right)$, was better when root sizes at harvest were averaged within each range $(10 \%=10 ; 10 \%$ to $20 \%=15$; and $25 \%$ to $35 \%=25$; respectively). The equation obtained was significant at $P>0.01$ (Fig. 2). Values observed in the regression plot represent marketable yield of cut-and-peel carrots harvested at three root size ranges; therefore, variation in mass occurs within the same root size at harvest.

This study should be extended by harvesting the carrot roots with $>50 \%$ of the roots with diameter $>2 \mathrm{~cm}$ in order to determine when the marketable yield starts declining, using smaller ranges to obtain a better predictor of marketable yield.

\section{Conclusions}

Our objective was to determine the field production factors affecting the processing of cut-and-peel baby carrots. Under the conditions of this study, the RH III at a PD of 321 plants $/ \mathrm{m}^{2}$ gave the highest fresh and cut mass of cut-and-peel baby carrots. However, percent waste after cutting was constant for the three RH, and treatments with 197 plants $/ \mathrm{m}^{2}$ had the lowest percentage of waste after cutting. Graded mass, the most variable criterion in the processing of cut-and-peel baby carrots, was significantly affected by RH and SL. The percent graded waste was greater at RH I than at RH III. Four SL produced more graded waste than did five or six. This may be a reflection of the effect of SL on length and shape of the carrots. RH III gave the lowest projected total waste, because it reduced waste produced during the grading step. In addition, RH III gave the best marketable yield, which was not affected by PD and SL. Also, with RH III, population density affected the processing of cut-and-peel baby carrots through all phases prior to the determination of graded mass. Graded mass was affected by the quality (length and shape) of the carrot roots and by SL; six lines per bed resulted in longer carrots, but made no significant differences in marketable yield. Therefore, the use of the lower PD of 197 plants $/ \mathrm{m}^{2}$ could reduce seed cost without affecting processed marketable yield.

Our overall conclusion is that RH III performed the best in terms of root yield and quality for baby-style carrots. PD affected total carrot yield, but no other quality parameters, and SL influenced root quality in terms of shape and length. Additional work is suggested to determine the effect of other $\mathrm{RH}$ categories.

\section{Literature Cited}

Agung, S. and G.J. Blair. 1989. Effect of soil bulk density and water regime on carrot yield harvested at different growth stages. J. Hort. Sci.
64:17-25.

Barnes, W.C. 1936. Effects of some environmental factors on growth and color of carrots. Cornell Agr. Expt. Sta. Memoir 186.

Bleasdale, J.K.A. 1973. Control of size and yield in relation to harvest date of carrot root. Acta Hort. 27:134-142.

Dainello, F.J. 1994. The Texas vegetable commercial production guide. Texas Agr. Ext. Serv., College Station.

Eckhoff, J.L.A., A.D. Halvorson, M.J. Weiss, and J.W. Bergman. 1991. Seed spacing for nonthinned sugarbeet production. Agron. J. 83:929-932.

Goldman, I.L. 1995. Differential effect of population density on shape and size of cylindrical red beet (Beta vulgaris L.) genotypes. J. Amer. Soc. Hort. Sci. 120:906-908.

Gray, D. and L.R. Benjamin. 1993. Controlling the size of carrot-The roles of seed quality and plant density. Acta Hort. 354:47-54.

Robinson, E.F. 1969. Carrot population density and yield in an arid environment. Agron. J. 61:499500.

Salter, P.J., I.E. Currah, and J.R. Fellow. 1980 Further studies on the effects of plant density, spatial arrangement and time of harvest on yield and root size in carrots. J. Agr. Sci. 94:465-478.

White, J.M. 1992. Carrot yield when grown under three soil water concentrations. HortScience 27:105-106.

White, J.M. 1994. Carrot row position on a raised bed and yield relationships. Proc. Florida State Hort. Soc. 107:105-107.

White, J.M. and J.O. Strandberg. 1979. Physical factors affecting root growth: Water saturation of soil. J. Amer. Soc. Hort. Sci. 104:414 416. 